\title{
MISCELIANEA GEOGRAPHICA
}

Vol. 14/2010 pp. 169-176

\author{
Barbara Nowicka \\ University of Warsaw \\ Faculty of Geography and Regional Studies \\ Department of Hydrology \\ e-mail: benowick@uw.edu.pl
}

\section{ESTIMATION OF THE DEGREE OF EXTREMALITY OF HIGH-WATER FLOWS IN SELECTED RIVERS IN POLAND IN 1971-2006}

\begin{abstract}
The paper presents the results of estimation and comparison of risk of extreme floods on rivers of various hydrological regime. The hypothesis that extreme events occur with the same frequency in all rivers was rejected. The limit between extreme and common floods on 30 rivers from different geographical regions of Poland was defined on the basis of standardized flow-duration curve in 1971-2006. These analyses resulted in designing five curve groups. Four measures of flood magnitude have been proposed. The time distribution of extreme events during the last decades was estimated for the most dynamic rivers.
\end{abstract}

Key words: extreme flood, threshold values, standardized flow-duration curve, hydrological regime.

\section{INTRODUCTION}

Peak flows vary in magnitude. The occurrence of extreme flows is attracting more attention nowadays. Their characteristics is applied to the flood risk assessment or planning of hydropower plants; it should also be taken into account in protection of river valley ecosystems. When discussing the results of global climate changes, the following questions are often asked:

- What is the degree of the variability of peak flow magnitude (degree of extremality) in various physicogeographical conditions?

- Did an extremalisation occur at the turn of the $21^{\text {st }}$ century? Extremalisation is here understood as the increase of the share of highest flows in the daily flow hydrograph.

The basic difficulty in investigations of this type is the lack of a commonly agreed upon definition of streamflow magnitude at which a high-water is regarded as an extreme event. In this paper we define an extreme high-water as "a high-risk event, outside the scope of common ex- 
perience". Such events are clearly distinct as compared with other events, which occur very regularly. Their values of daily flow differ significantly from those of a normal flow (median) and occur incidentally. They can last as long as several months, as it is exemplified by snow melt floods. To make this definition more exact, it is necessary to start a discussion on the estimation method of the critical value $Q_{\mathrm{gr}}$ on the flow hydrograph such that flows above it can be regarded as unexpectedly high (extreme).

In this paper we attempted to accomplish two tasks:

- to determine the methodology of the estimation of the streamflow threshold value and to estimate the variability of the threshold values of extreme flows;

- to estimate and compare the degree of extremality of peak flows in selected rivers.

The calculations have been based on daily mean streamflow values in 1971-2006, grouped by years and months. It has been attempted to determine the threshold flow values based on the analysis of the flow-duration curves. The study used the longest possible empirical sample from a large number of rivers from various regions of Poland, encompassing the same period.

\section{RESEARCH METHODOLOGY}

In determining extreme high-water, many criteria are used to determine the cut-off value separating extremely high flows from other streamflows. Threshold values of flow can have various character: hydrological (main flows) or economic. To the second group belong certain flows whose determination requires a knowledge of local conditions (e.g., flow at alert level). One can encounter suggestions to use, when determining critical values, the flow corresponding approximately to the bankful discharge of the river channel proper. This be misleading, since the occurrence of water on flood terraces is a natural phenomenon and occurs often. Another approach to the determination of the borderline value of extreme flow is to accept an arbitrary flow with a low occurrence probability, calculated on the basis of maximum values of yearly or half-yearly flow from a multi-annual period (Niedźwiedź et al., 2004; Zwoliński, 2008).

In this paper, the threshold values of the extreme flow have been determined on the basis of the analysis of flow-duration curves. The ordering of the daily mean flow values into a decreasing sequence allows to indicate for how long during the observations a given flow value was reached and exceeded (Weglarczyk, 2005). To compare rivers with different hydrological regimes, the exceedence curves have been modified. Daily flows $Q_{d}$ have been related to the normal flow $Z Q$ from the observation time:

$$
K_{d}=Q_{d} / Z Q
$$


where: $K_{d}$ is the ratio of exceedence of $Z Q$. The time axis is expressed in percentage of the size of the entire sample $(N)$. Realizing that the shape of the flow-duration curve is strongly dependent on the length of the measurement series, we have tried to use the longest measurement series possible. Such series make it possible to perform a comparative analysis of rivers and to capture regional regularities (Tomik, Żelaziński, 1970). A serious limitation on the selection of empirical data was the need to ensure that the measurements be continual and that the sample come from the same period for a large number of catchments. Analyses were based on available data from IMGW from 36 years $(1971-2006, N=13149)$.

To determine the threshold value of extreme flows, a distinct change in the increase of the largest values of the coefficient $K_{d}$ was sought. The increase was manifested by the change of the inclination angle of the upper branches of the curve and by the decrease of density of empirical points (Fig. 1). A greater inclination of the curve was interpreted as an "unexpectedly" high exceedence of the value of normal flow. A smaller inclination was linked with an "unexpected" increase in duration of high flows. To make the bend of the curve visible, the abscissa was presented in logarithmic scale. Extreme flows singled out in this way were described with four parameters which allow to compare the degree of extremality of the highest flows of the rivers studied:

- the coefficient of threshold discharge $K_{g r}[-]$ :

$$
K_{g r}=Q_{g r} / Z Q
$$

- the coefficient of the maximum exceedence $Z Q K_{\max }[-]$ :

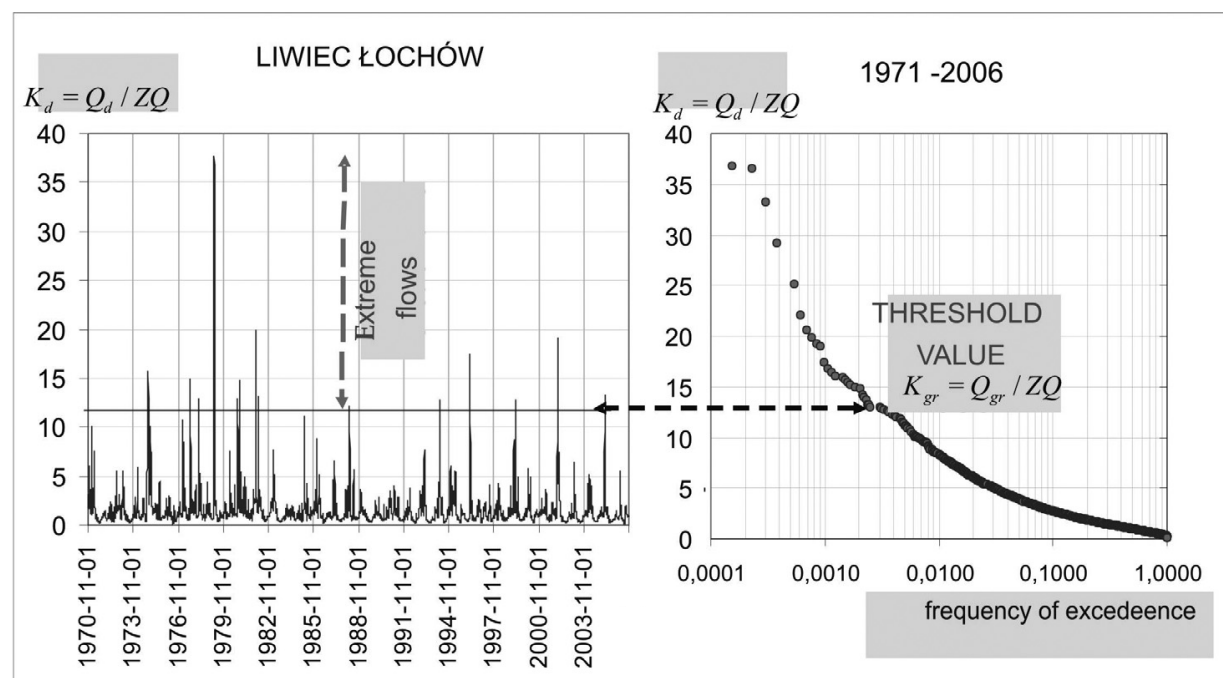

Fig. 1 Determination of the threshold value of the extreme high ratio of normal flow exceedence in the Liwiec river at the Łochów profile (1971-2006). 


$$
K_{\max }=Q_{\max } / Z Q
$$

where: $Q_{\max }-$ the largest flow determined during the observation period;

- the "threat" coefficient $Q[-]$, characterising the ratio of the maximum flow increase to the threshold value $Q_{g r}$ :

$$
\Psi=\left(Q_{\max }-Q_{g r}\right) / Q_{g r}
$$

- the frequency $n$ [\%] of exceedence of the threshold value $Q_{g r}$ in the period under investigation for $\Delta t=24$ hours. (5)

Thirty rivers draining catchments with surface area from 30 to $2500 \mathrm{~km}^{2}$ have been chosen for the study (Fig. 2). The selection took into account a

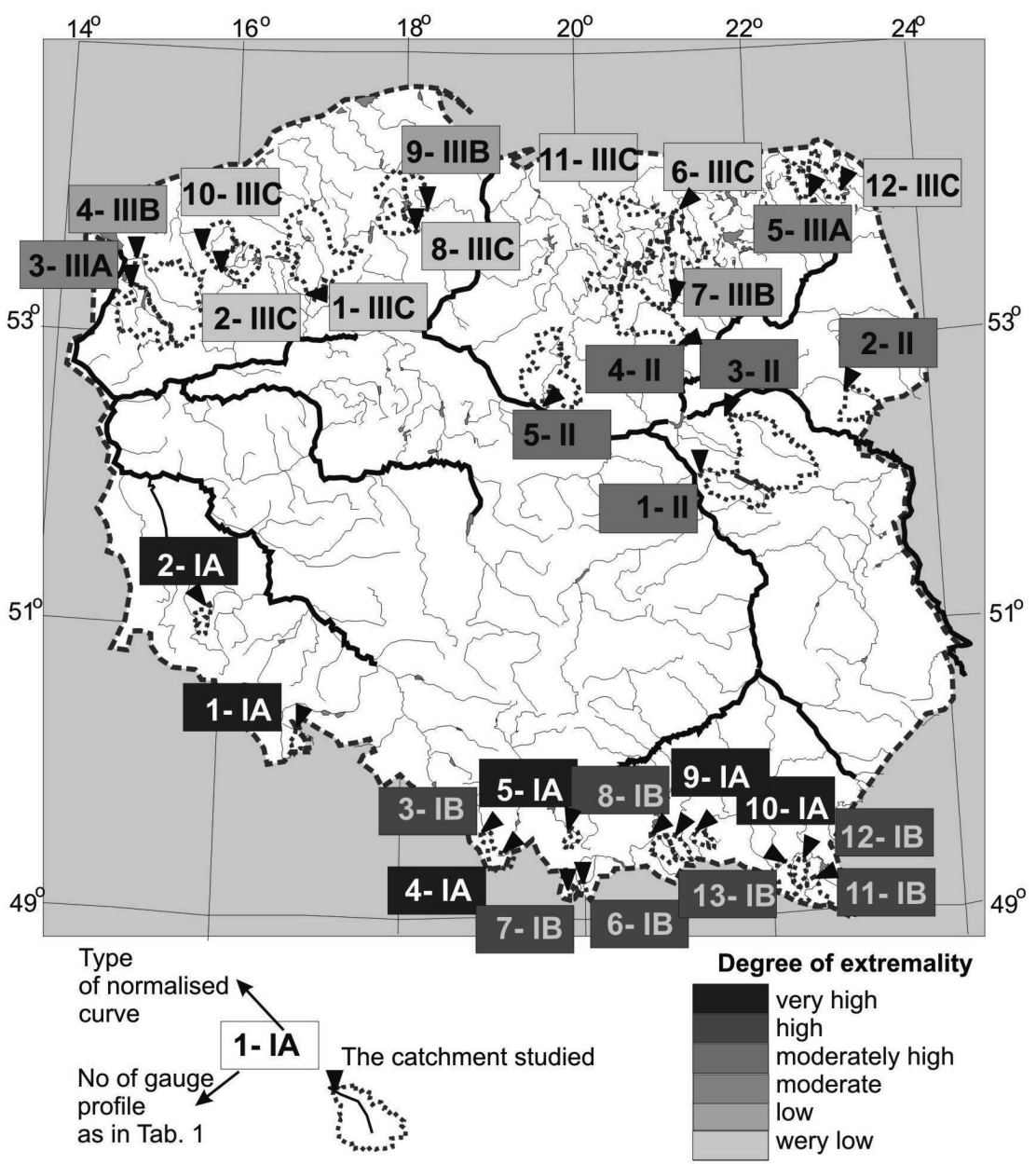

Fig. 2 Degree of extremality of rivers studied 
variety of hydrological regimes and locations in various physicogeographical regions. The rivers selected had as long as possible overlapping measurement series, including big floods at the end of the $20^{\text {th }}$ century. This requirement was a serious limitation. As a result, young glacial regions are represented by 13 rivers with snow regime from weak to strong (Dynowska, 1994). Some of them flow through lakes which modify their runoff conditions. Another five rivers drain old glacial lowlands; their hydrological snow regime is strong or medium. The remaining rivers drain mountain and sub-mountain regions. Their regimes vary significantly: from a strong snow regime in the Beskidy mountains to snow-rain or rain-snow ones.

\section{THE RESULTS OF THE STUDY}

The rivers studied have regionally varied maximum flows $Q_{\max }$. A comparison of normalised values shows that in the period under investigation 1971-2006 the maximum flow was from 3 to 511 times greater than the normal flow $Z Q$. At the same time, in $90 \%$ of events daily flows of rivers $Q_{d}$ did not exceed the value $10 Z Q$ (Fig. 3). The greatest changes in the course of upper branches of normalised flow duration curves occurred in fewer than $1 \%$ of cases. The threshold flow $Q_{g r}$ is observed at various event frequencies $n$, which depends on stability of streamflow. In mountain and foothill rivers [IA] the threshold values of extreme flows $Q_{g r}$ occur at a much lower frequency of daily flow exceedence $n$ (from 0.03 to $0.2 \%$ ) than in lowland rivers (from 0.1 to $1.7 \%$ ). The highest value is reached in rivers of young glacial regions, which is related to their long, often measured in months, highwater duration. At the same time the threshold values of the extreme flow $Q_{g r}$ are lowest in these rivers (less than $4 Z Q$ ), while in mountains they reach $85 Z Q$ (Table 1, Fig. 3).

Table 1. Measures of "extremality" of high-water flows of rivers in separate groups (1971-2006)

\begin{tabular}{|c|c|c|c|c|c|c|}
\hline \multirow{2}{*}{\multicolumn{2}{|c|}{$\begin{array}{c}\text { Type of normalised } \\
\text { flow-duration curve } \\
\text { of the daily river } \\
\text { flow }\end{array}$}} & \multirow{2}{*}{$\begin{array}{l}\text { Degree of } \\
\text { extremality }\end{array}$} & \multirow{2}{*}{$\begin{array}{c}\text { Coefficient } \\
\text { of } \\
\text { threshold } \\
\text { discharge } \\
K_{g r}\end{array}$} & \multicolumn{3}{|c|}{ Measures of extremely high discherges } \\
\hline & & & & $\begin{array}{l}\text { coefficient of } \\
\text { maximum } \\
\text { exceedence }\end{array}$ & $\begin{array}{c}\text { „threat" } \\
\text { coefficient } \\
\Psi\end{array}$ & $\begin{array}{l}\text { frequency of } \\
\text { exceedence } \\
\text { of threshold }\end{array}$ \\
\hline \multirow{2}{*}{$\begin{array}{l}\text { Mountains } \\
\text { and foothills }\end{array}$} & I A & very high & $20-85$ & $145-511$ & $2,5-7,0$ & $0,03-0,2$ \\
\hline & I B & high & $12-46$ & $35-352$ & $1,5-7$ & $0,09-0,2$ \\
\hline $\begin{array}{l}\text { Old-glacial } \\
\text { lowlands }\end{array}$ & II & $\begin{array}{l}\text { moderately } \\
\text { high }\end{array}$ & $9-20$ & $24-46$ & $1-2$ & $0,09-0,2$ \\
\hline \multirow{3}{*}{$\begin{array}{l}\text { Young- } \\
\text { glacial } \\
\text { lowlands }\end{array}$} & III A & moderate & $6-8$ & $9-14$ & $0,5-0,6$ & $0,4-0,6$ \\
\hline & III B & low & $3-5$ & $4-7$ & $0,15-0,5$ & $0,1-0,5$ \\
\hline & III C & very low & $0-3,5$ & $2,5-5$ & $0,1-0,8$ & $0,2-1,7$ \\
\hline
\end{tabular}



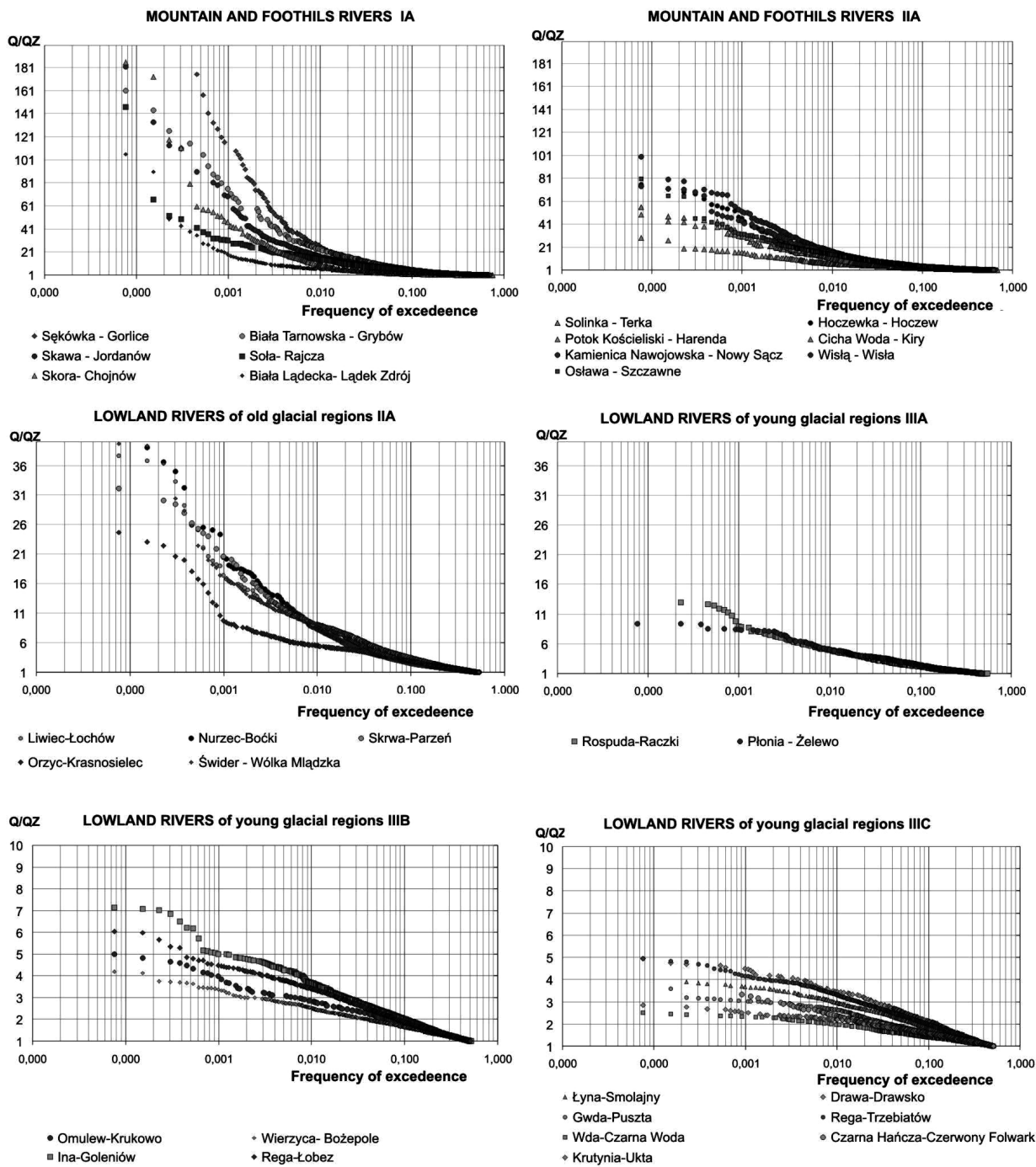

Fig. 3. Variability of the shape of normalised flow-duration curves of the daily river flow $K_{d}$ - exceedence ratio $Z Q$

Analysis of the shape of normalised curves of 30 Polish rivers allowed to divide them into 6 groups (Fig. 3, Table 1). Two groups contain mountain and foothill rivers. The first one [IA] is characterised by a very large highwater dynamics, significant culminations and short duration. They have a very high "threat" coefficient: from 2.5 to 7.0. The threshold flows of extreme flows are very large here: from 20 to $85 Z Q$. Rivers from these groups occur both in the Sudety mountains and in the Outer (Western) Carpathian mountains. 
The second group [IB] is represented by mountain rivers whose daily flows are more stable. Despite of this, their maximal values reached up to $355 Z Q$, hence their high "threat" coefficient (Table 1). The threshold values of extreme flows were somewhat lower than the previous ones (Table 1). The Tatra mountains streams differ from other rivers of this group, since despite their high-mountain character, they are more similar to the rivers from the next group; this can be a result of the occurrence of karst which modifies the hydrological regime of the runoff.

The next group [IIA] consists of river flowing through old glacial regions (Fig. 3). The highest flows vary here from $24 Z Q$ to $46 Z Q$. As a result, the "danger" coefficient varies between 1 and 2 , although threshold flows do not exceed $20 Z Q$.

The next three groups [IIIA-C] are characterised by young glacial rivers. The shape of the curves is here influenced by the existence of lakes in the catchment, which take up between $2 \%$ and $8 \%$ of the catchment surface area. Some lakes are open and strongly modify runoff conditions. As can be concluded from Fig. 3, the runoff of these rivers is very stable. Therefore, in group IIIC the upper branches of flow-duration curves "flatten out" significantly. This effect is strengthened by the occurrence of snow melt floods of long duration. An extreme example of this is the Czarna Hańcza River. In the case of this lakeland river it was not possible to distinguish its extreme high-water by the method suggested. In the case of the remaining rivers, the threshold values determined varied between 2 and $14 Z Q$. The "threat" coefficient of the maximal flow in these rivers was very low and did not reach 1.

\section{SUMMARY}

The determination of threshold values delimiting extremely high events is of importance for the estimation of temporal and spatial distributions of these events. In this paper, we decided not to use a constant threshold value - this would be tantamount to an a priori assumption that extreme events occur with the same frequency in all rivers, which could raise doubts when the rivers compared have various hydrological regimes. Arbitrary acceptance of constant threshold values of the critical flow $Q_{g r}$ with the same exceedence probability for all the rivers studied may lead to under- or overestimation of the number of extreme flows. We can make the criterion of the estimation of the threshold value corresponding to the extreme flow more specific on the basis of an analysis of daily flows, and in the case of comparative analyses of rivers, on the basis of the daily coefficient $K_{d}$ of the exceedence of $Z Q$. When determining threshold values $Q_{g r}$, a good solution seems to be the application of daily flow-duration curves. This method, however, requires a further improvement. The determination of the threshold value $Q_{g r}$ on the basis of the shape of curves is subjective, which is well 
known from the method of runoff hydrogramme separation. A solution might be the search for the analytic form of the curves.

When interpreting the results one should take into account the time step of the event record. In the case of conventional series of data (taken every 24 hours, at 6 UTC), short-duration, sudden peak flows may remain unrecorded, or else flows forming only a part of the peak flow (related to wave propagation or recession and not to its culmination) will be recorded.

The use of the flow-duration curves makes it necessary to use a long measurement series, which is a serious limitation for many rivers in Poland. A possible solution to that may be the use of regional relationships. The analysis of the shape of modified curves of 30 Polish rivers allowed to divide them into several regional groups. Unambiguous methodological assumptions, which would make it possible to describe the relationship between the shape of a curve and the physicogeographical conditions of the catchment, have not been yet established.

The shape of the upper branches of the modified flood-duration curves varies very much and depends on the regional characteristics of high-water. A distinct "flattening out" of the curves is characteristic for young glacial rivers with long-lasting high-water. In very dynamic rivers and where highwater happens sudden, the curves are steeper. An exact description of these deviations can be applied in regional characteristic of floods. The measures of extremality of high-water in rivers proposed here mirror the specific features of the individual rivers to a large extent and can be applied in the analysis of flood risk and taken into account in the determination of alert levels.

\section{REFERENCES}

Dynowska I., 1994, Reżim odpływu rzecznego [River runoff regime], plansza 32.3 [Sheet 32.3] Odpływ rzeczny [River runoff] [in:] Atlas Rzeczpospolitej Polskiej [Atlas of the Republic of Poland], IG PZ PAN, PPWK im E. Romera S.A, Warszawa.

Lis-Turlejska M., 2004, Rozpowszechnienie traumatycznych zdarzeń oraz objawów potraumatycznych w nieklinicznej próbie studentów wyższych uczelni [Distribution of traumatic events and post-traumatic symptoms in a non-clinical sample of college student population] [in:] J. Streulau (ed.), Osobowość a ekstremalny stres [Personality vs. Extreme stress], GWP Gdańsk, 100-118.

NiedźwiedźT., UstrnulZ.,MichalczykZ., StarkelL., 2004,Zdefiniowanieekstremalnychzdarzeńmeteorologicznych, hydrologicznych oraz geomorfologicznych [Definition of extreme meteorological, hydrological, and geomorphological events]. Prezentacja MS Power Point w Sosnowcu, w dn.13.12.2004. [MS PowerPoint presentation in Sosnowiec on 13 December 2004]

Tomik T., Żelaziński J., 1970, Rozkłady czasów trwania przepływów na terenie Polski [Distributions of discharge durations in Poland], Prace PIHM, 100, 17-32.

Węglarczyk S., 2005, Probabilistyczna interpretacja krzywej czasu przewyższenia przepływu [Probabilistic interpretation of the flow-duration curve], Wiad. Instytutu Meteorologii $i$ Gospodarki Wodnej, XXVIII (XLIX), 3-4, 51-63.

Zwoliński Z., 2008, Wybrane zjawiska ekstremalne pojezierzy polskich [Selected extreme events of Polish lakelands], Landform Analysis, 8, 98-106.

English translation: Małgorzata Mikulska 